УдК 657.01

\title{
ПРОБЛЕМИ ТА ПЕРСПЕКТИВИ РОЗВИТКУ ОБЛІКУ В УМОВАХ ЦИФРОВОЇ ЕКОНОМІКИ
}

\section{PROBLEMS AND PROSPECTS OF ACCOUNTING DEVELOPMENT IN THE DIGITAL ECONOMY}

\author{
Шендригоренко Марина Трохимівна \\ кандидат економічних наук, доцент, \\ Донецький національний університет економіки і торгівлі \\ імені Михайла Туган-Барановського \\ ORCID: https://orcid.org/0000-0002-5841-6784 \\ Лядська Віталія Валеріївна \\ здобувач вищої освіти, \\ Донецький національний університет економіки і торгівлі \\ імені Михайла Туган-Барановського \\ ORCID: https://orcid.org/0000-0003-0591-3346 \\ Shendryhorenko Marina, Lyadska Vitaliia \\ Donetsk National University of Economics and Trade \\ named after Mykhayilo Tugan-Baranovsky
}

\begin{abstract}
Цифрова економіка заснована на цифрових технологіях, що тісно пов'язані з електронними, а також із цифровими товарами та послугами. У статті досліджено актуальні питання щодо концептуальних, теоретичних і практичних основ цифрової економіки, перспектив її розвитку та впливу цифрових технологій на інноваційний розвиток і суспільний прогрес. В умовах цифрової економіки функції бухгалтера розширюються, при цьому зростає коло компетенцій та обов'язків. Потреби роботодавців обумовлюють необхідність підготовки кваліфікованих фрахівців, здатних розв'язувати складні спеціалізовані завдання та прикладні проблеми у сорері обліку, аналізу, контролю, аудиту, оподаткування. Для цього необхідно використовувати в навчальному процесі останні досягнення економічної науки, а також систематично підвищувати кваліфрікацію та дотримуватися норм професійної етики.
\end{abstract}

Ключові слова: цифрова економіка, бухгалтерський облік, інформація, цифррові дані, облікова інформація, інфрормаційні технології.

Цифровая экономика основана на цифровых технологиях, тесно связанные с электронными, а также с циорровыми товарами и услугами. В статье исследованы актуальные вопросы концептуальных, теоретических и практических основ цисровой экономики, перспектив ее развития и влияния цисровых технологий на инновационное развитие и общественный прогресс. В условиях цифровой экономики фрункции бухгалтера расширяются, при этом растет круг компетенций и обязанностей. Потребности работодателей обусловливают необходимость подготовки квалифицированных специалистов, способных решать сложные специализированные задачи и прикладные проблемы в сфере учета, анализа, контроля, аудита, налогообложения. Для этого необходимо использовать в учебном процессе последние достижения экономической науки, а также систематически повышать квалификацию и соблюдать нормы профессиональной этики.

Ключевые слова: цифровая экономика, бухгалтерский учет, информация, цифровые данные, учетная инфрормация, информационные технологии.

The article examines topical issues regarding the conceptual, theoretical and practical foundations of the digital economy, prospects for its development and the impact of digital technologies on innovative development and social progress. The main purpose of the study is to study the problems and prospects of accounting in the digital economy. The following methods were used in the study: epistemological - to reveal the basic concepts related to the digital economy; analysis, synthesis, induction, deduction, abstraction, idealization and generalization - to identify and assess problems of accounting development in a digital economy; systematization and generalization - to study the prospects of improving the efficiency of accounting. In the digital economy, the functions of the accountant are 
expanding, while the range of competencies and responsibilities is growing. The needs of employers necessitate the training of qualified specialists who are able to solve complex specialized tasks and applied problems in the field of accounting, analysis, control, audit, taxation. To do this, it is necessary to use in the educational process the latest achievements of economics, as well as to systematically improve skills and adhere to the norms of professional ethics. Accounting in a digital economy requires flexibility of the accounting process and relevant knowledge from accounting staff in the implementation and use of new generation information systems and technologies in order to form timely, reliable information about the enterprise. Information and communication and digital IT technologies provide an opportunity to intensify processes, implement modern advances in computer technology. Outlining the general mechanism of transformation of accounting, control and management systems, request for creation of a single information space necessitates conceptual research of the synergetic effect of IT modernization (digitalization) of accounting. It is concluded that digital development is characterized by revolutionary changes and the most important result of digitization in modern conditions is the automation of services, characterized by instability, instability, «innovation-digital explosions», the latest discoveries that operate according to new principles. The application of technological IT innovations in the methodology of accounting changes the form of its organization, increases the level of professional competencies and responsibilities of personnel, brings the information support system to a qualitatively new level of transparency, security, efficiency, relevance. It is especially important to use IT innovations to improve document management. Thanks to IT modernization of accounting procedures the following tasks are solved: collection, grouping and ordering of information flows; fast access and issuance of information; reducing the interval between obtaining information and entering it into the database; reducing the risk of errors in accounting and adoption processes solutions that allow the company to avoid distortion of information in accounting.

Keywords: digital economy, accounting, information, digital data, accounting information, information technology.

Постановка проблеми. Економічний розвиток країни характеризується впровадженням сучасних інформаційних технологій. Цифрова економіка являє собою тип економіки, що характеризується активним впровадженням і використанням цифрових технологій зберігання, обробкою й передачею інфрормації в усі сфрери людської діяльності. Основною проблемою розвитку цифрової економіки в Україні $€$ відсутність системної державної політики у даній сорері.

Виділення не вирішених раніше частин загальної проблеми. Наявність вимоги до єдиного інорормаційного простору стає головною ознакою цифрової епохи. Таким чином, шлях розвитку бухгалтерського обліку повинен втілювати результати сучасних цифрових технологій, фрундаментальної та прикладної науки. Збір, опис, зберігання та обробка даних у цифрову епоху економіки змінюється і стає логічним поєднанням сучасного наукового розвитку в рамках бухгалтерської інсрормаційної системи. Сучасні проблеми вимагають від бухгалтера хоча б базового розуміння інорормаційно-комунікаційних технологій; наявність цифрових навичок стає основною вимогою до персоналу. Тому існує проблема удосконалення змісту інновацій в системі бухгалтерського обліку, що відображає вже існуючі практики циоррової економіки.

Аналіз останніх досліджень та публікацій. Дослідженню проблем та перспектив розвитку обліку в умовах цифрової економіки присвячені роботи багатьох авторів, а саме: Вишневського О.С., Крауса Н.М., Матвейчука Л.О., Голобородька О.П. та багато інших.
Науковці у своїх роботах розглядають умови та напрями розвитку цифрової економіки в Україні. Однак, потребують ретельного дослідження актуальні питання щодо визначення практичних перспектив удосконалення обліку в умовах цифррової економіки.

Формулювання цілей статті (постановка завдання). Головною метою статті є вивчення проблем та перспектив розвитку бухгалтерського обліку в умовах цифррової економіки.

Виклад основного матеріалу дослідження. Цифрова економіка $€$ віртуальним середовищем, яке доповнює реальність. Вона все більше пов'язана з традиційною економікою, що ускладнює чітке розмежування. Найважливішими продуктами циоррової економіки $€$ ті самі товари та послуги в традиційній економіці, що забезпечуються комп'ютерною технікою та цифровими системами, як і глобальна мережа Інтернет [1]. Вона має свої переваги, які полягають у збільшенні доступності постійних користувачів на певних ринках (товарів чи послуг), зменшенні трансакційних витрат, підвищенні ефрективності та конкурентоспроможності.

Вважаємо, що основними перешкодами для розвитку цисррової економіки в Україні $\epsilon$ фрінансові та юридичні. Фінансові заважають діяльності українських компаній на світових ринках, особливо щодо необмеженого надходження коштів на рахунки, відкриті в Україні. А юридичні не сприяють поширенню ідеології спільної економіки на внутрішніх ринках [2].

Інфрормація стає найважливішим джерелом конкурентоспроможності. Збір, опис, зберігання та обробка даних дозволяють отриму- 
вати цінну інформацію для подальшого використання у фрінансових процесах. Бухгалтер повинен вміти оцінювати, синтезувати аналітичні висновки та стратегічні пропозиції. Тоді поєднання технологічних інновацій та навичок бухгалтерського обліку стане ефективним.

Теорія і практика бухгалтерського обліку змінюється в сучасних умовах для інтеграції 3 IT-технологіями [4]. Представники даної профессії повинні мати певні навички, необхідні для конкурентоспроможності в цифровому соціально-економічному середовищі.

Розвиток бухгалтерського обліку у зв'язку з оцифруванням соціально-економічних відносин пов'язаний, насамперед, із впровадженням IT-засобів та технологій, що прагнуть подолати недоліки існуючої системи бухгалтерського аналізу та контролю [3]. Зусилля щодо підвищення чіткості, узагальненості та актуальності управлінської інфрормації стають рушійною силою для створення ефективної бухгалтерської одиниці, яка розуміє стратегію та цілі управління, і кожне завдання виконується завдяки перспективі подолання довгих або необов'язкових складних процедур 3 помилковими чи непотрібними результатами.

Оновлення цифрової трансорормації бухгалтерського обліку в майбутньому лише збільшиться, оскільки використання IT-інновацій дає змогу вирішувати нові проблеми, модернізувати концепції обробки та передачі інформації, сприяє ефективності бухгалтерських процесів. На додаток до звичайних фрункцій бухгалтерського обліку та звітності існує потреба в посиленні процесів управління та IT-послуг.

Вважаємо, що модернізація IT-бухгалтерії відповідно до вимог інфрормаційної економіки повинна складатися 3 програмного, інсрормаційного, організаційного та методологічного компонентів [5]. Ці компоненти стають найважливішими інфрормаційними системами, які інтегровані навколо веб-системи. Надійна та масштабована система аналізу інфрормації забезпечує підтримку та автоматизацію процесів управління всіма компонентами організації.

Якісний розвиток цифрових послуг в бухгалтерському обліку має на меті не тільки мінімізувати людський фрактор у прийнятті рішень, а й отримати швидку якісну інформацію про процеси. Водночас, оцифрування - це інструмент для створення, впровадження та використання переваг системи бухгалтерського обліку, що вдосконалюється IT-технологіями [5].

Висновки. Цифрова економіка $\epsilon$ ефективною основою для розвитку державного управління, економіки, бізнесу, соціальної ссрери та суспільства в цілому. Успішний розвиток цифрової економіки в Україні вимагає ефективної державної політики для подолання «цифррового розриву» та стимулювання розвитку цифррової економіки. Не можна досягти успіху в розвитку цисррової економіки за відсутності відповідних нормативних актів, стратегії економічного розвитку, заснованої на цифрових технологіях. Але не менш важливим є підготовка фрахівців, зданих працювати 3 новітніми технологіями.

У період цифрової трансформації соціально-економічних відносин консерватизм в бухгалтерському обліку не повинен втручатися в інновації. Цифрова трансформація бухгалтерського обліку стане обов'язковим і важливим кроком для ефективної діяльності організації. Інфрормація, комунікації та цифррові технології дають можливість активізувати процеси контролю, обліку та управління.

Бухгалтерський облік в умовах цифрової економіки потребує гнучкості облікового процесу і відповідних знань від працівників бухгалтерії при впровадженні та використанні інфрормаційних систем і технологій нового покоління 3 метою фрормування своєчасної, достовірної інсрормації про діяльність підприємства.

Майбутні наукові дослідження повинні бути зосередженні на критичному дослідженні ключових концепцій системи бухгалтерського обліку в умовах цифррової економіки.

\section{СПИСОК ВИКОРИСТАНИХ ДЖЕРЕЛ:}

1. Веретюк С.М., Пілінський В.В. Визначення пріоритетних напрямків розвитку цифррової економіки в Україні. Наукові записки Українського науково дослідного інституту зв'язку. 2016. № 2. С. 51-58.

2. Канцедал Н.А. Бухгалтерський облік цифрової епохи: розширення термінологічних кордонів. Бухгалтерський облік та фрінанси. 2019. № 1(83). C. 29-34. DOI: 10.33146/2307-9878-2019-1(83)-28-34

3. Пивоваров Ю. Навіщо Україні цифррова економіка. URL: http://nv.ua/ukr/

4. Цисррова економіка. Про нові можливості для України. URL: https://nv.ua/ukr/opinion/kubiv/tsifrovaekonomika-pro-novimozhlivosti-dlja-ukrajini-2282520.html

5. Руденко М.В. Цифровізація економіки: нові можливості та перспективи. Економіка та держава. 2018. № 11. C. 61-65. DOI:10.32702/2306-6806.2018.11.61 


\section{REFERENCES:}

1. Veretiuk C.M., Pilinskyi V.V. (2016) Vyznachennia priorytetnykh napriamkiv rozvytku tsyfrovoi ekonomiky v Ukraini [Identifying priority areas for the digital economy in Ukraine]. Naukovi zapysky Ukrainskoho naukovo doslidnoho instytutu zviazku, no. 2, pp. 51-58. (in Ukrainian)

2. Kantsedal N. (2019) Accounting in the Digital Age: Expansion of Terminological Boundaries. Accounting and Finance, no. 1(83), pp. 28-34. DOI: 10.33146/2307-9878-2019-1(83)-28-34 (in Ukrainian)

3. Pyvovarov Yu. Why Ukraine digital economy. Retrieved from: http://nv.ua/ukr/ (in Ukrainian)

4. Digital economy. About new opportunities for Ukraine. Retrieved from: https://nv.ua/eng/opinion/kubiv/tsifrova-ekonomika-pro-novi-mozhlivosti-dlja-ukrajini-2282520.html (in Ukrainian)

5. Rudenko M.V. (2018) Tsyfrovizatsiia ekonomiky: novi mozhlyvosti ta perspektyvy [Digitizing the Economy: New Opportunities and Perspectives]. Ekonomika ta derzhava, no. 11, pp. 61-65. DOI: 10.32702/2306-6806.2018.11.61 (in Ukrainian) 